\title{
The Ruling of Paper Money Usage: Analysis Based on the Evolution of Currency Development
}

\author{
Salmy Edawati Yaacob ${ }^{1}$ \\ ${ }^{1}$ The National University of Malaysia, Malaysia \\ Correspondence: Salmy Edawati Yaacob, The National University of Malaysia, Malaysia. E-mail: \\ salmy1001@yahoo.com
}

Received: October 8, 2013 Accepted: November 25, 2013 Online Published: January 27, 2014

doi:10.5539/ass.v10n3p86 URL: http://dx.doi.org/10.5539/ass.v10n3p86

\begin{abstract}
Efforts to regain and elevate the usage of gold dinar in Malaysia have created various polemics either from the legal viewpoint, economic transactions, and the position of currency law. Views from some quarters advocating gold dinar as the currency demanded in Islam have implications on the use of paper money today. Consequently, some gold dinar activist groups in Malaysia forbid the use of paper money due to the lack of gold backing. This has created confusion amongst the communities on the law of paper money usage. Thus, the aim of this study is to analyze the views of the Muslim scholars regarding the forbidden use of paper money and the Islamic point of view. This analysis is based on the various phases of world currency development beginning from the first phase (paper currency as a receipt of debt), the second phase (a means of payment/fulus), the third phase (paper money as gold value backed) and the fourth phase (paper money as a principal currency). This study is in the form of qualitative by using the library research approach. The result of this study shows that the use of paper money is permissible because currently paper money has become the world principal money and no longer as a receipt of debt. The Council of Islamic Fiqh Academy (Majlis Majma al-Fiqhi al-Islami) $5^{\text {th }}$ session held in $1402 \mathrm{H} / 1982 \mathrm{AD}$ is also with a resolution that the use of paper money is permissible.
\end{abstract}

Keywords: currency law, gold dinar, paper money, currency evolution

\section{Introduction}

Legal disputes over gold dinar and paper money exist due to various gold dinar activists with different faiths in their efforts to regain and elevate the usage of gold dinar as a currency. Gold dinar and silver dirham were seen as a form of Islamic currency used during the Prophet Muhammad's s.a.w. (peace be on him) era until the era of the ${ }^{\mathrm{c}}$ Ottoman government in 1924. While paper money was first emerged during the mid-era reign of the 'Ottoman government known as al-Qa'imah.

The World Murabitun Movement (Murabitun) who champions the physical usage of gold dinar holds that the gold dinar gold dinar is the currency of Islam and the use of paper money is illegal. According to Vadillo (2002), the paper money system we have today is forbidden (haram) because it is a receipt of debt or dayn. Islam does not allow debt as an exchange and their usage must be limited as a private contract. His argument is based on a history in the book of al-Muwatta' (Malik ibn Anas t.th), which stated how Marwan ibn al-Hakim had ordered his guards to repossess the receipts of debt (which were traded in the market of al-Jar before the goods arrive) and return them to their owner.

This movement also considers that the paper money is prohibited due to the inherent element of gharar (deception) and riba' (usury) in the system. Gharar is the basis of unfair profit in the exchange of paper money. This is because the replacement of real money of dinar and dirham with artificial paper money. The excessive profit or surplus $\left(r i b a^{\prime}\right)$ is created through the bank's methods of creating multiplier credits. This money also does not allow people to redeem gold as a collateral. Next Vadillo (2002), Hosein (2008) and Zuhaimy (2003) concluded that paper money and banking institutions were the symbol of the presence of riba'. Riba' is a clear prohibition in Islam and therefore paper money is prohibited. However, this view is seen in contravention of those who try to uphold the usage of gold dinar as a backup for value if paper cannot be made as a currency. 


\section{Literature Review}

Among the responses from the views above are views of the earlier Muslim scholars (ulamas) that leads to the paper money as a receipt of debt. One of them is the view of al-Husayni $(1329 \mathrm{H})$, in which he has stated that banknote (notes) as a document of debt on its holder and this document is used as a medium of exchange and payment largely because it is lighter and easier to carry. Al-Husayni $(1329 \mathrm{H})$ opined that the transaction with this paper was similar with the al-hiwalah transaction (transfer). However, this view is refuted by several Muftis in Malaysia like Tan Sri Dato' Seri (Dr.) Hj. Harussani bin Hj. Zakaria (Perak State Mufti), Datuk Wira Hj. Rashid Redza bin Hj. Md. Saleh (Malacca State Mufti), Dato Paduka Haji Sheikh Abdul Halim Riza (Kedah State Mufti) and Mohamad Shukri bin Mohamad (Kelantan State Deputy Mufti). All of them are of the view that the use of paper money is permissible and the Muslim community may continue using it. The prohibited part of this system is the implementation mechanism that set the course towards riba', speculation and fraud. The paper money is not prohibited and it is not a receipt of debt because it has a preset value. If Malaysia wishes to reintroduce the usage of gold dinar, then the mechanism needs to be clear and definite. Meanwhile Syed Nazmi Bin Tuan Taufek (Islamic Affairs Officer, Department of State Mufti of Terengganu) concludes three factors why the paper money today is not prohibited. The factors are (Edawati, 2005):

1) paper money is not a receipt of debt because it has a value predetermined by the government;

2) the use of paper money is permissible as long as it does not violate the Islamic law. What is wrong today is its conduct and application by certain parties on the currency; and

3 ) the monetary system which began with barter system, followed by gold and then the paper money system is in accordance with the changing of times and not simply to falsify mankind and definitely not to make it forbidden.

Whereas, the Mufti Harussani states that if a currency has no sound basis for exchange or backing then it forms part of gharar. According to Ibn Manzur (t.th), gharar means exposing a person or a person's assets unmindful of destruction, and generally gharar means danger, catastrophe and risk. While al-Sarakhsi (1979) explained that gharar could occur in conditions of uncertainty about the existence of certain unknowns such as some hidden outcomes or consequences. Gharar is forbidden in Islam because it can lead to disputes and conflicts and any dispute and conflict in muamalat is forbidden in Islam. Gharar is something that is uncertain and gives rise to doubt, similar to the problem of riba' which is clearly forbidden by Allah S.W.T. If the monetary system cannot escape from the elements of gharar and riba' then the system is not in accordance with the Islamic law (syara') (Joni Tamkin \& Mohd Ridhwan 2009). Meanwhile, currency speculation and manipulation will lead to oppression and tyrannise the small nations. Therefore, in order to create a system that is more just and harmonious, Islam demands its followers to seek for an alternative financial system that is more just and stable (Edawati, 2005).

Mufti Rashid Redza concurs with the above statement and proposes for the return of gold dinar as a currency. According to him, it is a good move and in conformity with the requirements and tenets of Islam. Gold dinar was practised during the Prophet Muhammad's s.a.w. time and was a valuable currency, stable and fair. Gold dinar has been proven to have many advantages compared with the existing currency. Hence, the study by Salmy Edawati (2005) concluded that the alternative to the floating paper money system was gold based system or gold dinar system. Gold dinar is a viable alternative currency because of its characteristics that fulfil the currency requirement of Islam namely: intrinsic value, stable and durable. These characteristics can safeguard a currency from riba', inflation and manipulation.

The Prophet Muhammad s.a.w. had been using dinar and dirham currency in daily transactions. Meanwhile, the fulus currency was used as a supporting currency to the smaller and cheaper business transactions. From that leads to the words 'dinar' and 'dirham' being mentioned in several verses of al-Quran, as in verse 75 of surah Al-'Imran, verse 20 of surah Yusuf, verse 59 of surah al-Nisa', and verse 19 of surah al-Kahfi. This is because these verses were revelled during the Prophet's s.a.w. time and it is not peculiar if all the concepts and characteristics of currency being mentioned in the al-Quran are based on gold dinar and dirham currencies. Therefore, it is imperative to fine tune the discussion of currency in Islam so as to resolve the currency problems emerged today. Hence, this gives rise to disputes among the ulamas on the position of paper money being used today. Is paper money permissible in Islam or not?

Hence, the disputes and contradictory views in determining the exact ruling on the use of paper money today should be discussed and coordinated. A clear ruling on this paper money is vital because it involves the daily muamalat of the Muslims. Besides, paper money will also be the medium (wasilah) in the implementation mechanism of gold dinar value backed currency system. 


\section{Method}

This research is a qualitative study using the approach of library research and historical studies. Content analysis was used for data collection process. Meanwhile, the process of data analysis is carried out through the textual analysis method, evaluation of the views of Islamic scholar on changing phases of world currency.

\subsection{Analysis Based on the Views of the Islamic Scholar on the Changing Phases of World Currency}

The paper money being used today gives rise to many different opinions among the ulamas in determining the ruling of its uses. This is because paper money in a form of currency exists only after the pass on of the Prophet Muhammad s.a.w. and there is no clear ruling regarding the use of paper money in the al-Quran, al-Hadis nor old scriptures. Hence, the question of rulings regarding the paper money will be viewed through the evolution of it usages beginning from the earlier creation of paper money until today.

According to a study by Hassan 1999, fatawas (edicts or legal decisions) on the fixing of rules regarding the currency were issued based on the development of currency beginning from the use of commodity money, metallic money (dirham and gold), and subsequently the paper money. Paper money has also undergone several developmental phases beginning from phase one: paper money as a letter of declaration in substitute of money or receipt of debt (bank money), phase two: paper money as gold value backed, phase three: paper money as a means of payment, and phase four: paper money as a complete substitute for gold and silver money.

3.1.1 First Phase: Paper Money as a Letter of Declaration in Substitute of Money or Receipt of Debt (Paper Money as a Bank Money)

History has recorded that China was the first country to use paper money in $1368 \mathrm{M}$. Meanwhile, community during the Romans has started using paper money which is regarded as a declaration receipt in substitute for gold and for storing gold in a safe place such as the goldsmiths, eminent people, trustworthy religious people or safe deposit boxes stashed in secured places (storage). The declaration letters in substitute of money represent the gold belongs to the respective owners and can be redeemed at any time from those secured places. The declarations are normally with IOU (I Owe You) printed on it. Keepers of the gold in storage will impose certain charges such as the custodial charges, storage and for reducing the risk of theft (Goldfeld \& Chendler 1981). The government of the ${ }^{\mathrm{C}}$ Ottomans in $1256 \mathrm{H}(1804 \mathrm{AD})$ has produced the first paper money known as the al-Qa'imah. The use of this paper money only lasted for 23 years before it was officially rescinded in $1278 \mathrm{H}$ (1816AD). However, in $1293 \mathrm{H}$ the al-Qa 'imah was reproduced only to be discontinued a while later because it was not well received by the public. In $1332 \mathrm{H}$, the al-Qa'imah was reproduced for the third time and this time its usage was enforced through legislation. The paper money of al-Qaimah continued to be used until the fall of ${ }^{\mathrm{c}}$ Ottoman Turkish government in 1924 ( $\left.{ }^{\mathrm{C}} \mathrm{Ali}, 1983\right)$.

Therefore, most ulamas of thought between the years 1886-1924 was centred on the paper money as a declaration letter in substitute of gold or receipt of debt. Some of the ulamas ruled that paper money was a debt document while some of them rejected it. The ulamas who ruled paper money as a debt document or a receipt of debt were Ahmad al-Husayni, Muhammad Amin al-Shanqiti, Salim bin Abd, Allah bin Samir and Habib bin Sumayth. They were of the opinion that the paper money essentially did not fall into the category of a currency because paper money was just a document of evidence that the bank owed the holders of gold. In the event of a transaction using the documents, the value backed gold or metal being stored would be a measure. Therefore, the paper money merely served as a document representative of the gold deposited in the bank.

Ahmad al-Husayni (1329H) stated that:

"Sometimes the government produced its debt documents known as 'banknote', as a debt document against the holder of those documents. Those documents are being used as a medium of exchange and payment because it is light and easy to carry around in one's pocket or in hand in a large amount. To gain the trust of the public, owners of those documents can redeem them for gold at any time according to the values written on those documents. Sometimes the government also gives permission to the banks to produce these debt documents with specific conditions. Under these circumstances, the public trusts and have high regards on the debt documents until the banks and the government are encountered with problems when payment processes slow down or the banks withdraw those values. This makes the document worthless and causes loss of confidence on debt documents. The rule on this transaction is the same as the al-hiwalah transaction (transfer)".

This view was refuted by several ulamas like Ahmad Ridha al-Buraylawi and Ahmad Khatib al-Jawi who both lived during the era of paper money being used as declaration document in substitute of money. al-Zuhayli (1986), a contemporary ulama was also of the same view that paper money was not a debt document. 
Al-Buraylawi (t.th) states that:

"The opinion that states that paper money is a debt instrument i.e. the institution (banking) responsible in marketing this money as dues owed to the depositors of the dirhams. The bank issues a piece paper as a proof of debt and the amount owed. When the depositor presents that paper to the bank, the debt is paid and that paper is then returned to the bank. If the holder of that paper gives it to another people, this means the bank owes the second holder of the paper. In other words, the transfer of paper between the first holder to the second holder is a proof of debt transfer. The second holder will get the same value of debt due to him from the bank. The paper may continue to change hands in numerous times in tandem with the increase in transfer of debts. This is why it is called a debt document. Even children would understand that this sort of transaction will not occur in the heart of every person who transacts with the paper currency. They do not mean by this change; borrow, lend or transfer."

Al-Jawi (1329H) also provides evidences that paper money is not a debt document. Among the evidences are:

1) The paper money will lose its value due to physical damage of the paper. For example, if a currency note (paper money) worth 10 dinars is burnt in a fire then the value of 10 dinars is gone. But, with the status of the paper money as a debt, the owner of the burnt paper money may claim the value of 10 dinars from the party issuing the paper money and its value.

2) When the holder of the paper money redeems the value from the issuing party, it deems the return of paper money to the issuer. Despite of this, the paper money will still be able to be resold with the same value. If the transaction is a debt, the debt free paper should not be resold.

Al-Zuhayli (1986) states that:

"It is not true to qiyas (analogize) paper money as a debt because debt is of no use to its owner, i.e. the person who gives the loan. Besides, ulamas do not compel zakat (tithe) payment on a price that is still in the form of debt unless it is delivered. This is because there is the possibility of loss or transactions being unpaid. On the other hand, paper currency can be of beneficial to its holder such as gold which is considered as having a price value on everything."

There are some ulamas who take the view that the physical paper of paper money has no value, as the value depends on the number written on the paper representing the gold stored. This view is true in the sense that the paper that serves as a medium during the time was a representative document of the amount of gold owned and kept in the bank. The views of the ulamas considered at the time were based on the development of paper money during the period as a representative document or a bank's receipt of debt. The period was between the years 1886 to 1914. This means that the argument of paper money as a receipt of debt or document representative is no longer relevant to be debated in today's time when the paper money today is already considered as the staple currency in world monetary system.

\subsubsection{Second and Third Phase: Means of Payment/Fulus and Paper Money as Value Backed}

At this stage, the bank document or deposit declaration receipt is not considered as money in totality because the institutions or the public that own this document will continue to convert it into a metal currency in a short while. This is because at the time, the metallic money (coins) have become the basic currency for most countries in the world. However, when the economies prosper, the documents or the bank receipts could not be redeemed soon enough and are always changing hands and circulate in the market and did not return to the issuer of receipts (the bank). The keepers of this gold soon began to realize these changes and find that most of the paper receipts issued are not returned to them for redemption. Only a small number came to redeem their gold or silver. The keepers of gold and silver then started to issue more receipts not representing the true value of gold stored. This happens due to the public's confidence of the keepers, whereas redemption can be done at any time they need it. Finally, bank receipts depart the medium of exchange and at one swoop take over the function of basic currency.

At this time, there have been other opinions of the ulamas who regard paper money as fulus money (chipped money or fraction money). This shows that the status of paper money is on par with fulus in term of price value. Meanwhile, in terms of fiqh law, some ulamas apply the rules of paper money as the same as fulus while some ulamas qiyas it with gold and silver. Among the ulamas supporting the opinions of paper money as fulus are Muhammad Ridha al-Buraylawi, Ahmad al-Khatib al-Jawi, Muhammad ' Ulaysi al-Maliki, Sulayman al-Khalidi al-As ${ }^{\mathrm{c}}$ ardi and Muhammad Salamah Jabar.

According to al-Buraylawi (t.th), the copper money of fulus is originally a type of commodity which has eventually become the currency in circulation and is widely used by the people in the market. This is similar to the paper money. Paper is originally a type of commodity and now it is widely accepted as a currency in 
circulation in the market and well received by the people. The numbers written on the paper money indicate the price value. Al-Buraylawi also is of the opinion that the obligation of zakat is compulsory on the paper money due to its own intrinsic value and non-debt receipt. However, he classifies the paper currency as a wealth of riba' because the value of paper money is fixed through market collaboration whereas the public has no right to interfere with the contract between the parties involved.

In addition, al-Khatib $(1330 \mathrm{H})$ is of the view that value of paper money is on par with gold and silver in its physical and value properties. However, zakat is not obligatory on the paper money because paper is not included in the list of zakat obligatory metals such as gold or silver. According to al-Khatib, paper money has no ${ }^{c}$ ilah as gold, therefore it could either be sold or turn into debts with repayment of same or different values or through deferred payment or otherwise. Paper money follows the same rules as copper fulus in totality to the extent that zakat is non obligatory. The same applies to the wealth of riba' where paper money has no element of riba' ${ }^{\prime}$ ilah as gold and silver. This view is similar to the view taken by the Maliki ulamas who state that the obligatory of zakat only confined to livestock, selected grains, fruits, gold and silver and business property. Paper nor copper are zakat non-obligatory so appropriately neither paper money and fulus. Nevertheless, al-Zarqa (n. d.) has different view with al-Buraylawi and al-Khatib where for him, even though the function and status of paper money qiyas that of fulus, from fiqh law paper money is subjected to the rules of gold and silver as zakat obligatory and thus the same goes for the wealth of riba'.

There are also the conflicting views of ${ }^{\mathrm{c}}$ Abd Allah ibn Basam, Muhammad Salamah Jabar and Sulayman al-Khalidi in which they support the view of equating (qiyas) paper money with fulus as a circulating currency accepted by all. Therefore, they agree that paper money is not a wealth of riba' and sales of debt can be transacted either through deferred or immediate payment. They also stress that even though the paper money and fulus follow the same currency rules, paper money is subjected to zakat obligation because paper money is part of asset and zakat obligation is meant to cleanse the asset of the Muslim (Hassan, 1999).

These are all the opinions expressed during the simultaneous circulation of paper money with gold dinar and silver dirham currency in the market. These opinions are no longer tenable after the paper currency today become the mandatory currency and the use of gold as currency is no longer allowed. The ulamas liken the paper money with fulus because fulus is largely circulated in the market during the time as well as dinar and dirham and this situation no longer exists today.

\subsubsection{The Fourth Phase: Paper Money as Full Fledge Substitute for Metallic Money}

At the fourth stage, the production of money is no longer controlled by any law but has been dominated by large nations i.e. the United States of America. However, at this stage, the laws play a role in governing the production of money. For example, beginning from 1993, a legislation was introduced prohibiting the use of gold or gold backed receipts as a currency except for collection or authorized for specific reasons. Meanwhile beginning from 1971, President Richard Nixon officially broke the ties between paper money and gold. After that, paper money has become the major and mandatory currency in the monetary system today.

In currency issues, the circulations of gold and silver as currency has been repealed by the international laws since 1914. After the end of Bretton Woods in 1971, the gold backed currency system was officially cut off from the global monetary system. Thus, there are difficulties in using gold and silver as currency whence paper money is widely received by the market as a medium of exchange and valuation. Thus, the paper money is seen as something that is easy to implement. Therefore, based on the fiqh method of 'Easy things to do not dismissed due to difficulties' (al-Maysur La Yasqutu bi al-Ma sur) the zakat obligation on assets (paper money) cannot be dismissed with the repeal of circulation of gold and silver currency. The monetary application of paper money is seen as easily accepted by the public as the currency of today.

\section{Results and Discussions}

The Muslim ulamas nowadays have issued their views on the paper money where they consider the present paper money as distinctive from fulus, gold and silver. The paper money is one of the many developmental phases of money that has started out as a commodity, metallic coins and henceforth paper money. These three types of currencies are different from one another. The similarities they have are being the medium of exchange and their values determined by the market.

Through these views, several Islamic fiqh laws on paper money are being issued today, such as the law on riba', zakah, mudharaba (sleeping partnership) and several other laws relating to gold and silver. Based on these views also, the fatawa of the al-majma ${ }^{c}$ al-fiqhi was issued during the fifth conference held in $1402 \mathrm{H}$, with the decision that the use of paper money as currency is permissible. The laws on the use of paper currency decided during the 
Council of Islamic Fiqh Academy 5th session held in 1402H/1982AD are the following (Bank Dubai al-Islami, $1411 \mathrm{H})$ :

1) The origin of paper money is gold and silver. The 'ilah of riba' that occurs between them, based on the strongest view amongst the ulamas, is due to their values (thamaniyyah). The ${ }^{c}$ ilah is not limited to only gold and silver even though originally it is so.

2) The currency that exists today is of value because of the government guarantee on these values. The community has accepted it as a storage device and as a means of payment even if its value is not the paper but the numbers or writings printed on it. This makes the existing currency valuable (thamaniyyah) and has taken the place of gold and silver in its use.

3) ${ }^{C}$ Ilah that is on gold and silver clearly exists in today's currency.

Therefore, members of the Council of Islamic Fiqh Academy have decided that the paper currency is impartial which takes all the laws on gold and silver. That includes the legal prohibition of the riba' al-fadl and riba' al-nasa', the compulsory zakah and other laws. This is based on the qiyas (analogy) of the existing currency on gold and silver. Hence, based on the analysis on the change phases of the currency, it can be concluded that the paper money used today is permissible in Islam. Therefore, Islam permits the use of any type of currency whether it is paper money or gold coins. Figure 1 shows an overview of the relationship between the fatawas on the ruling of paper money issued by the Islamic jurists based on the four phases in the evolution of paper money development. 


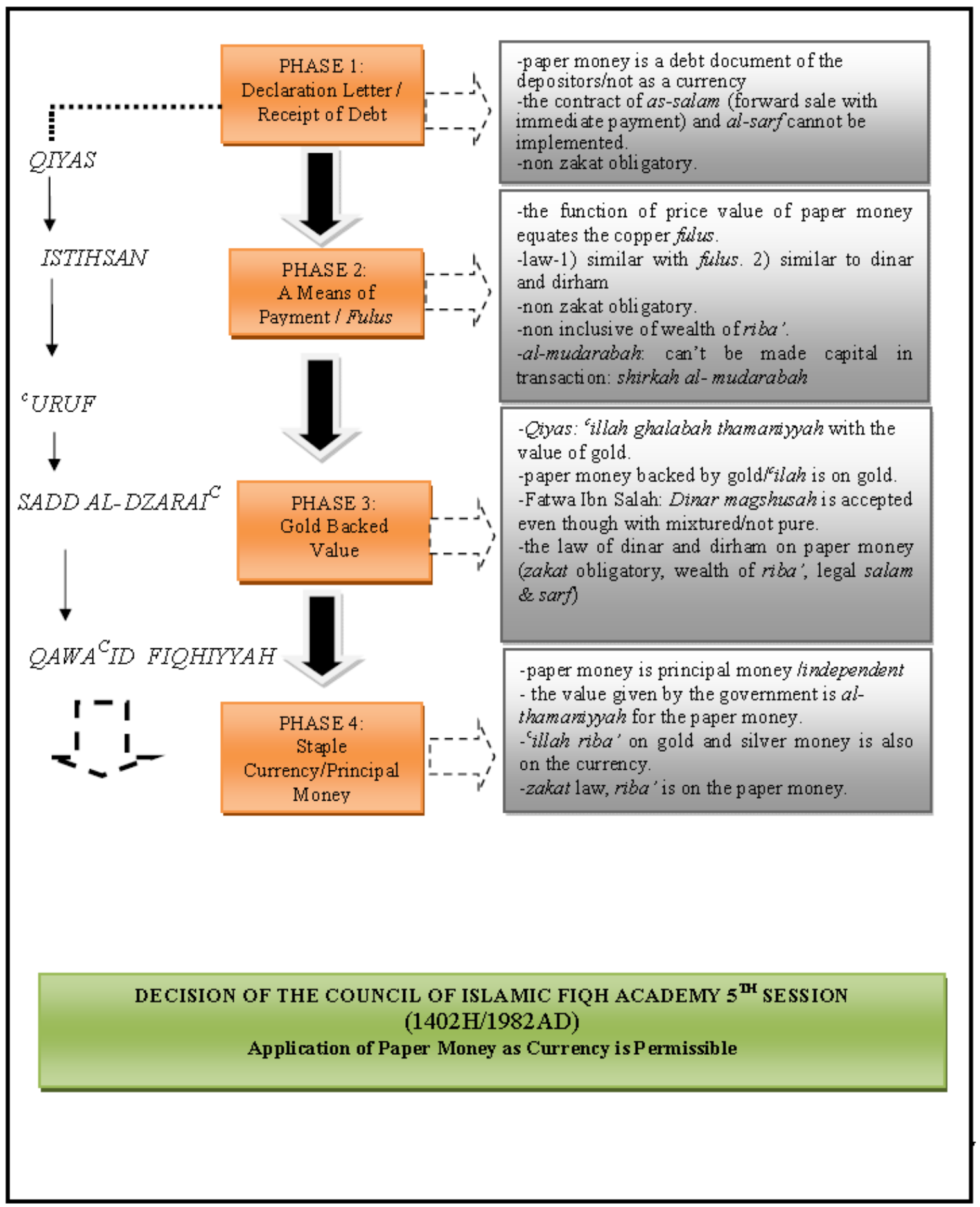

Figure 1. Development of fatawas on the law of paper money usage

\section{Conclusion}

Although the terms 'dinar 'and 'dirham' or gold and silver are mentioned in the al-Quran and al-Hadith, however, there is no evidence (nas) of directions or commands to use both currencies. The use of the terms 'dinar 'and 'dirham' merely reflects the form of money used at that time (during the revelation) but this does not mean that it is the duty of Muslims to use 'dinar 'and 'dirham' (gold and silver currency) today. Therefore, the use of currency other than gold and silver is not disapproved in Islam. Besides, decision on the laws of paper money can be viewed through the evolution of the development of paper money. 
Historical data shows that the evolutionary development of paper money is made up of four phases. The first phase is the phase of the use of 'Letter of Declaration' or 'Receipt of Debt'. Meanwhile, the second phase is the use of paper money as a 'Means of Payment' or 'Fulus'. The third phase is the period in which paper money is backed by gold and then, in the final phase where the paper money has become the world's major currency (independent) or the principal. The fuqahas (Islamic jurists) have given their fatawas that the laws on the use of paper money is based on these developmental phases of paper money. Hence, the laws on paper money today cannot be equated with representative money, fulus or receipt of such debt in the previous phases.

\section{References}

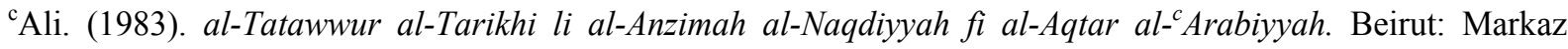
Dirasat al-Wahdah al- ${ }^{\mathrm{c}}$ Arabiyyah.

Bank Dubai al-Islami. (1411H). Majallat al-Iqtisad al-Islamiy. Dubai: Bank Dubai al-Islamiyy.

al-Buraylawi, A. R. (n. d.). Kifl al-Faqih al-Fahim fi Ahkam Qirtas al-Darahim. Lahour: t.tp.

Goldfeld, S. M., \& Chendler, L. V. (1981). The Economics of Money and Banking. New York: Harper \& Row.

Hasan, A. (1999). al-Awraq al-Naqdiyyah al-Iqtisadi al-Islami: Qimmatuha wa Ahkamuha. Damshiq: Dar al-Fikr.

Hosein, I. N. (1997). The Importance of the Prohibition of Riba in Islam. New York: Masjid Dar al-Quran.

al-Husayni, A. (1329H). Bahjah al-Mushtaq fi Bayan Hukm Zakat Amwal al-Awraq. Cairo: Kurdistan.

al-Jawi, A. K. (1329H). Raf u al-Iltibas ${ }^{c}$ an Hukm al-Anwath al-Mut ${ }^{c}$ amil biha baina al-Nas. Mekah: Turqi al-Majidiyyah.

Borhan, J. T., \& Aziz, M. R. A. (2009). International business transaction from the Islamic economics perspective. Jurnal Teknologi, 50(E), 87-99.

al-Khatib, A. (1330H). Iqna 'al-Nufus bi Ilhaqi Awraq al-Amwath bi ${ }^{c}$ Umlat al-Fulus. Beirut: al-Ahliyyah.

Anas, M. (n. d.). al-Mudawannah al-Kubra. Beirut: Dar Sadir.

Yaacob, S. E. (2005). Study of Possibility of Gold Dinar Implementation in Malaysia. Disertation (Master of Syariah), Department of Syariah and Management, Academy of Islamic Studies, University of Malaya, Kuala Lumpur.

al-Sarakhsi, M. A. (1979). al-Mabsut (Vol. 12). Beirut: Dar al-Ma ${ }^{\mathrm{c}}$ rifah.

Vadillo, U. I. (2002). The Return of the Islamic Gold Dinar. South Africa: Madinah Press.

al-Zarqa', M. A. (n. d.). al-Madkhal al-Fiqhiyyah. n.p.: Dar al-Fikr.

al-Zuhaili, W. (1986). al-Fiqh al-Islami wa Adillatuhu. Jil.. 4. Damshik: Dar al-Fikr.

Ismail, Z. (2003). Kembalinya Dinar Emas dan Dirham Perak. Johor : UTM Skudai.

\section{Copyrights}

Copyright for this article is retained by the author(s), with first publication rights granted to the journal.

This is an open-access article distributed under the terms and conditions of the Creative Commons Attribution license (http://creativecommons.org/licenses/by/3.0/). 